\title{
User perspectives of climate forecasts: crop producers in Pergamino, Argentina
}

\author{
David Letson ${ }^{1, *}$, Ignacio Llovet ${ }^{2}$, Guillermo Podestá ${ }^{1}$, Fred Royce ${ }^{3}$, Victor Brescia ${ }^{4}$, \\ Daniel Lema ${ }^{4}$, Gabriel Parellada ${ }^{4}$
}

\author{
${ }^{1}$ Rosenstiel School of Marine and Atmospheric Science, University of Miami, 4600 Rickenbacker Causeway, Miami, \\ Florida 33149-1098, USA \\ ${ }^{2}$ Facultad de Ciencias Agrarias, Universidad de Belgrano, Buenos Aires, Argentina \\ ${ }^{3}$ Department of Agricultural and Biological Engineering, University of Florida, PO Box 110570, Gainesville, \\ Florida 32611, USA
}

${ }^{4}$ Instituto Nacional de Tecnología Agropecuaria, Instituto de Economía y Sociología Rural, Buenos Aires, Argentina

\begin{abstract}
A necessary initial step in assessing the value of climate information for regional agriculture is to gauge user perceptions concerning the use of that information. We attempt to do so for cereal and oilseed production in Pergamino, Argentina, located in the Pampas, one of the world's major agricultural regions. A survey of 200 farmers identified climate forecast scale and the reliability of the source of forecast as critical obstacles to adoption. Users' incomplete knowledge of how El Niño-Southern Oscillation affects their region may also pose an obstacle to greater use of climate information. A related problem is that users sometimes confuse the different time scales of weather and climate forecasting. Research and outreach to downscaling forecasts temporally and spatially toward user communities would help close the gap of expectations between forecast user and provider, and would facilitate the trust building process between the two that must precede adoption.
\end{abstract}

KEY WORDS: Climate information · Attitudes $\cdot$ ENSO $\cdot$ Agriculture

\section{INTRODUCTION}

In the last $20 \mathrm{yr}$, agricultural use of climate information has increased dramatically (Changnon 1999). The tropical Pacific atmospheric-oceanic phenomenon known as ENSO (El Niño-Southern Oscillation) has important consequences for climate and for agriculture in many parts of the world. ENSO is a variation between normal conditions and 2 extreme states associated with warm or cold sea surface temperatures in the eastern half of the tropical Pacific Ocean. Research suggests a considerable potential value of ENSObased climate forecasts to agriculture (e.g., Adams et al. 1995, Solow et al. 1998). Surveys of the value of ENSO-based climate forecasts for agriculture include Johnson \& Holt (1997), Mjelde et al. (1998), Weiher

*E-mail: dletson@rsmas.miami.edu
(1999), and Rick Katz's internet site (www.esig.ucar. edu/HP_rick/agriculture.html).

Many studies estimating the economic value of climate forecasts assume users have an idealized response to the information. However, the economic impact of climate, anticipated by users who behave optimally, does not by itself argue persuasively for the economic value of climate information. Forecast dissemination and use are more complex than many researchers have assumed and may be impeded by technical, financial, and cultural barriers (Glantz 1996, Feldman 1989, Broad et al. in press). A necessary step in promoting agricultural use of climate information or in assessing its value is to gauge user perceptions concerning the use of that information (Lamb 1981, Stern \& Easterling 1999). As Morgan et al. (1992) advise, 'First, learn what people know and believe.' Neglecting the role of user expectations and preferences in defining and managing climatic risk neglects users' 


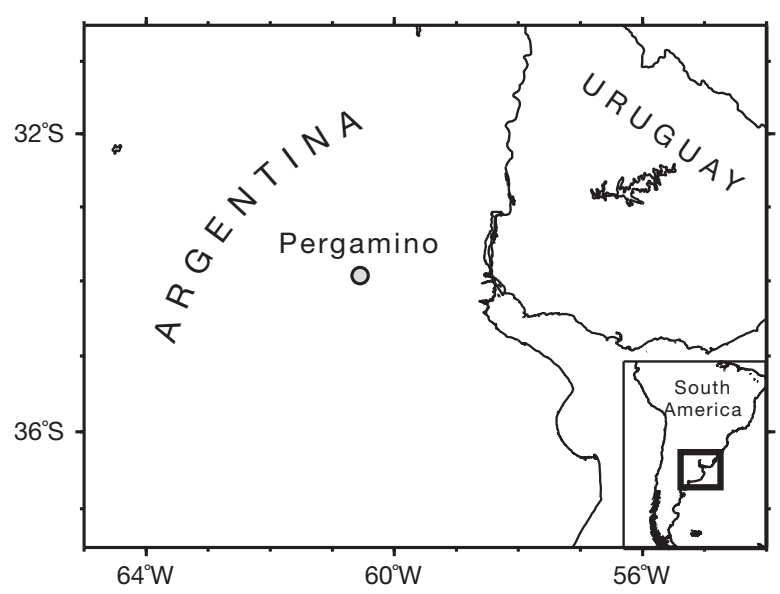

Fig. 1. The study area

priorities and may undermine our ability to provide useful information. Scientists need to know how the public is likely to respond to ENSO-based climate forecasts because those responses alter the economic influence of climatic impacts (Burns 1999). Policy makers should understand user needs, to realize the potential economic value from the emerging technology of ENSO-based climate forecasting (Changnon 1996).

To assess perceptions of ENSO-based climatic forecasting, we used focus groups and a user survey to approach cereal and oilseed producers in Pergamino, Argentina, located in the climatically favorable eastern portion of the Pampas, one of the world's major agricultural regions (Fig. 1). We focus on Argentina for several reasons. Argentina is a major agricultural producer. The value of its agricultural exports was 50 to $60 \%$ that of its overall exports and 5.5 to $9.6 \%$ of its GDP (gross domestic product) over 1989-1998 (InterAmerican Development Bank 1999). In Argentina, interannual climatic variability causes high variability in crop yields and returns (Parellada et al. 1998, Messina et al. 1999, Podestá et al. 1999a, Ferreyra et al. 2001). ${ }^{1}$ Since the economic reforms of 1991, rising grain prices, relative to those for beef, have induced an expansion of cultivated areas that amplifies the effects

\footnotetext{
${ }^{1}$ The Pampean ENSO signal has been well documented, both in terms of its effects on climatic variables and on agricultural production. During Niñas, maximum temperatures and radiation tend to be higher, while minimum temperature and rainfall tend to be lower than normal in the Pampas; the opposite tends to occur during Niños, though less markedly (Grondona et al. 2000). Through changes in temperature, rainfall and radiation, ENSO also affects crop yields. The most recent Niño (1997/98) enhanced regional crop production, particularly for maize and soybean (INTA/SAGPyA 1998). In contrast, Niñas tend to lower yields of maize, soybean and sorghum (Podestá et al. 1999a)
}

of anomalous climate (Basualdo 1995). ${ }^{2}$ The predominant soil in Pergamino is a typical Argiudoll (Paruelo \& Sala 1993). Characteristic crop rotations include maize, soybean, and a wheat-soybean relay. Median annual precipitation is $937 \mathrm{~mm}$. Hall et al. (1992) give a description of the climate, soils, and crop production systems in the Pampas. We take an empirical case study approach so that we can identify a specific context for climate information in agricultural decision making. However, the similarity in production scale, crops grown and technology in the Pampas to those in other major production areas suggests its broader relevance.

We proceed as follows: Section 2 reviews related literature and argues for a view of ENSO-based climate forecasting as an interactive social process rather than a technical innovation of obvious worth. Section 3 adds insights gained from direct interaction with potential users in Pergamino. Section 4 offers conclusions.

\section{RELATED LITERATURE}

Researchers have used a variety of approaches to promote the use of ENSO-based climate forecasts or to estimate their value. Many economic studies apply Bayesian decision theory to simulate ideal forecast responses (Wilks 1997, Stern \& Easterling 1999). In a recent example of ENSO phase forecast evaluation, Solow et al. (1998) considered: (1) climatic differences between ENSO phases, (2) the effects of these climatic differences on crop yields, (3) optimal cropping decisions with or without ENSO-based climate forecasts, and (4) the ultimate effects of individual farming decisions on agricultural commodity markets. Other studies based on simulated forecast responses include Mjelde et al. (1988) and Adams et al. (1995); Wilks (1997) provided a recent survey of such applications.

An alternative and complementary approach relies on observed decision making, where the emphasis is on how forecasts are interpreted and applied, rather than ideal responses (Stewart 1997, Stern \& Easterling 1999). Such an approach is desirable if users do not obtain maximum possible forecast value, perhaps

\footnotetext{
${ }^{2}$ In the last decade, Argentinian agriculture has experienced extensive restructuring because of economic reforms that lifted price controls and eased export restrictions. With increased access to world markets, there are fewer producers operating larger enterprises, with higher rates of input usage. The larger, more specialized producers can be expected to initiate use of seasonal forecasts. However, smaller scale operations, already under increasing economic pressures, may need to adopt technical innovations such as seasonal forecasts to survive
} 
because of the ways in which they do or do not use forecasts. Examples of this approach include Glantz (1977, 1982), Easterling (1986), and Pulwarty \& Redmond (1997).

A few studies overlap this dichotomy. Sonka et al. (1988) used a gaming approach to elicit information about forecast value, deriving actual decisions albeit in a hypothetical setting. Easterling \& Mendelsohn (in press) do not interpret actual or simulated decisions, and instead, as a reduced form approach, use a hedonic price model of climate and agricultural land values that treats regional differences in land values as an analogy for forecast value. Jochec et al. (in press) combine decision rules derived from focus groups with ecological and economic models to simulate forecast value.

This paper falls into the second category and is an empirical decision case study attempting to shed light on how decision makers use (or do not use) forecasts. Assumptions that potential users will adopt improved climate forecasts neglect critical issues (Feldman 1989). Such issues range from examining the consequences of alternative management to the technological, legal, economic, social and cultural frameworks that condition sectoral responses. Following the plea by Murphy \& Brown (1983) for forecast dissemination that is experimental and iterative, Pulwarty \& Redmond (1997, p. 394) state:

"Forecast "interpretation" should be viewed as a process involving ongoing evaluation of information on the physical conditions being forecast in the context of other decisions and information that potential users must consider throughout the year.'

Available empirical evidence supports the broader view of forecast use as a social process. In their interviews of potential forecast users, Pulwarty \& Redmond (1997) and Changnon et al. (1995) both found that simulation studies of the economic value of forecast information would make little difference in whether respondents would actually use forecasts. In their survey, Selley \& Wilson (1997) report a considerable lag between the development of risk analytical research tools and their application in agricultural extension activities. Because the Bayesian decision analysis for ENSO-based climate forecast use falls into this class of methods, some concern about when ENSO-based climate forecasts will become part of extension activities may be in order.

Routine availability of ENSO-based climate forecasts will not, by itself, increase agricultural incomes or lower production costs in ENSO-influenced regions. Climate information is but one of 3 parallel processes that comprise the forecasting process. In addition to the prediction itself, a communication process shares the prediction and a choice process focuses on decisions (Pielke
1998, Pielke et al. 2000). The research community's definition of a 'good' forecast does not necessarily agree with policy makers' or society's view of what is most important (Offutt 1993). Partly the problem is one of communication. Fischhoff (1994) identifies several problems in communicating forecasts, including ambiguity regarding the event being predicted and what is being said about it, and the relevance of the forecast for users' problems. In their review of forecasts for the 1997/98 Niño, Barnston et al. (1999) cite ambiguous descriptions of magnitude, time of onset, and duration. Also, different stakeholders have different preferences about what a forecast should do. Thus efforts to 'educate' the public are unlikely to make them see forecasts as experts do (Freudenburg \& Rursch 1994).

A more general but related concern is that research should be usable science that has demonstrable social value (Glantz 1996). To qualify, a research program must identify potential users and persuade them of its practical value (Pielke \& Glantz 1995). Similarly, Robinson (1992) argues that risky decision making will be improved by the mutual learning among scientists and stakeholders that would occur when science is done in a policy context. Such a scientific-stakeholder collaborative (Cohen 1997) can link scientific expertise ('What if?') with stakeholder knowledge ('So what?' and 'What should be done?').

We take an empirical case study approach in that our goal is to obtain a more accurate view of the users' decision process. As Yin (1994, p. 13) argues, the case study is especially useful as an empirical method 'when the boundaries between phenomenon and context are not clearly evident.' Forecasts are more likely to be adopted and to be useful science if the values, perceptions, and preferences of potential users become an integral part of the forecast process. Below we report our attempts to identify potential users' perceptions and needs.

\section{USER PERCEPTIONS AND NEEDS}

Many economic studies of ENSO (e.g., Mjelde et al. 1988, 1993, 1997, Adams et al. 1995, Solow et al. 1998) have focused on the technical limitations of forecast accuracy without considering issues such as the degree of user acceptance and the context of use (Funtowicz \& Ravetz 1990). An exception is Mjelde et al. (1996), who estimated the effect of US farm programs on forecast value. To promote forecast use or to estimate its value, we should seek to understand not only climatic effects but also their roles in users' lives (Fischhoff 1994). Elicitation of users' perceptions and needs provides a more detailed view of the forecast process. 


\subsection{Our data}

Our interactions with potential forecast users consisted of a series of open-ended interviews with 7 Pampean farm managers as well as 2 focus groups, each with producers and distributors, held in Buenos Aires and Pergamino (Podestá et al. 1997, Royce et al. 1997, Llovet 1998). The open-ended format of our interactions allowed the structure of users' preferences to emerge. Because the time intensity of interviews and focus groups limits sample sizes, we also surveyed 200 farmers to improve our ability to indicate the prevalence of these attitudes. Because the main purpose of the interviews and focus groups was to aid in the design of the survey questionnaire, our discussion here will focus on survey responses.

Sample design was driven by both practicality and by our goals of making forecasts more useful to more people. We selected 200 farmers based on the size of their operations and for ease of contact by Instituto Nacional de Tecnología Agropecuaria (INTA), the fed-

Table 1. User attitudes toward climate forecasts $(n=100)$. Exact wordings of questions are available upon request from the authors

How much does climate information influence your decisions?
$27 \%$ somewhat
$33 \%$ moderately
$14 \%$ not at all
$16 \%$ a little

$10 \%$ strongly

How important was climate information in 1997/98, compared to previous years?

$52 \%$ more important $\quad 5 \%$ less important

$34 \%$ same

$9 \%$ climate information is not important

Did the 1998/99 Niña forecast influence your decisions? $58 \%$ no

$42 \%$ Yes

Which decisions would you be most likely to change in response to a climate forecast?

$\begin{array}{ll}27 \% \text { area planted } & 27 \% \text { planting date } \\ 22 \% \text { cultivar } & 17 \% \text { fertilizer } \\ 3 \% \text { irrigation } & 2 \% \text { pesticides } \\ 2 \% \text { other } & \end{array}$

My decisions are most influenced by...

$33 \%$ output price expectations $22 \%$ crop rotations

$16 \%$ climate information $\quad 11 \%$ input costs

$9 \%$ soil tests

$9 \%$ other

In 1997/98, my decisions were most influenced by... $31 \%$ output price expectations $\quad 20 \%$ crop rotations $20 \%$ climate information $\quad 11 \%$ input costs $7 \%$ soil tests

$11 \%$ other

How does this region's climate compare with others' close by?

$43 \%$ similar

$37 \%$ somewhat different

$11 \%$ quite different

$9 \%$ don't know eral government agency that conducted the interviews in January and February of 1999. Average farm size in our sample was 450 ha. We surveyed producers managing less than 1000 ha, because earlier contacts suggested that larger operations likely already use ENSObased climate forecasts. Also, smaller producers in our focus groups appeared reluctant to adopt other technological innovations such as the use of personal computers and no-till planting techniques, and thus might be appropriately targeted for outreach efforts. Data are available upon request from the first author.

Survey respondents answered questions about climate variability as a source of income risk and the ability of ENSO-based climate forecasts to alleviate that risk. A split sample design allowed us to ask a larger number of questions, the responses to which are detailed in Tables 1 \& 2, and also enabled us to validate our sample by comparing the consistency of responses across the 2 sub-samples (not shown here). In initial, descriptive questions, $70 \%$ of the 200 respondents listed soybeans as their principal crop, followed by maize $(14 \%)$, sunflower $(6 \%)$ and wheat $(4 \%)$. Earlier research found ENSO signals in the yields of maize and soybeans, but not those for sunflower and wheat (Podestá et al. 1999a). Most of the 200 respondents rented at least some of their land (54\%) and machinery

Table 2. Users' knowledge of ENSO impacts on regional climate and crop production $(\mathrm{n}=100)$. Exact wordings of questions are available upon request from the authors

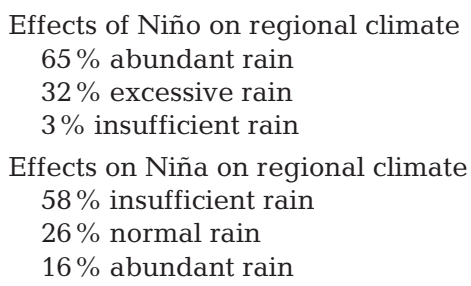

Effects on Niña on regional climate $58 \%$ insufficient rain

$26 \%$ normal rain

$16 \%$ abundant rain

Which crop is most influenced by climate information? $\begin{array}{ll}48 \% \text { maize } & 6 \% \text { all the same } \\ 30 \% \text { soybean } & 4 \% \text { none }\end{array}$ $8 \%$ sunflower $2 \%$ other $2 \%$ wheat

Effects of Niño on maize yields $86 \% \operatorname{good}$ $8 \%$ bad

$4 \%$ none $2 \%$ don't know

Effects of Niña on maize yields $27 \% \operatorname{good}$ $42 \%$ bad

$18 \%$ none $13 \%$ don't know

How did you learn about the regional climate? $\begin{array}{ll}61 \% \text { own experience } & 5 \% \text { trade publications } \\ 18 \% \text { family elders } & 3 \% \text { other farmers }\end{array}$ $6 \%$ extension $\quad 7 \%$ other

How well do you know the regional climate? $56 \%$ moderately $\quad 11 \%$ little $27 \%$ some $6 \%$ quite well 
(76\%). Another indication of vulnerability to climate variability is that most crop production is rainfed, with few producers $(7 \%)$ saying they had any irrigated cropland.

Two limitations of our sample deserve mention. First, because our contacts were not randomly selected, respondents are likely to be more receptive to extension efforts than producers at large. Thus, our results may overstate attitudes concerning the usefulness of ENSO-based climate forecasts. Second, we did not weight our responses to make them more representative of the local farming population. Recent, rapid changes in cropping patterns, farm size and land ownership would make the most recent census (1988) an unreliable basis for such a weighting.

\subsection{User attitudes toward ENSO-based climate forecasts}

This portion of the survey asked 100 respondents about their willingness to use ENSO-based climate forecasts. Pergamino farmers are aware of ENSO and are concerned about climatic variability in general, although some doubt the usefulness of ENSO-based climate forecasts (Table 1). All producers we surveyed knew 1997/98 had been a Niño and 1998/99 was a Niña. Perhaps not surprisingly, given our focus on small producers, more than a few respondents stated they had little $(16 \%)$ or no use $(14 \%)$ for ENSO-based climate forecasts. As an influence on their production decisions, respondents ranked climate information third $(16 \%)$, behind output price expectations (33\%) and crop rotations $(22 \%)$. In reaction to ENSO-based climate forecasts, respondents said they would be most likely to change the crop mix $(27 \%)$, planting date $(27 \%)$, cultivar $(22 \%)$, and fertilizer amounts $(17 \%)$. Regarding crop mix, the proportions of maize, soybean, and sunflower can be adjusted until June or July, which indicates when forecasts would have to be available.

A recurring theme in our findings is that the 1997/98 Niño was a milestone in the development of awareness and concern about ENSO in our study region. About half the respondents $(52 \%)$ said that climate information had been particularly important in 1997/98, called by some researchers 'the Niño of the century' (e.g., McPhaden 1999). Also, the ranking of influence on respondents production decisions changed slightly when we asked them to reflect specifically on 1997/98: $31 \%$ cited output price expectations as most important for that growing year, while climate information and crop rotations were each cited by $20 \%$. Those citing the particular importance of climate information in 1997/98 were more likely to be younger and to operate larger farms and thus had relatively more to gain from learning to use climate information. Wilcoxon rank sum tests revealed a negative correlation between respondent age and climate information importance $(p=0.0198)$ and a positive correlation between farm size and climate information importance $(p=0.0145)$. Because of its magnitude and the perceived predictive success of meteorologists, the 1997/98 Niño had an important influence on respondents' attitudes toward ENSO-based climate forecasts. Of course, that kind of attention may be a mixed blessing. ${ }^{3}$

Most respondents (58\%) did not change their decisions after hearing the Niña forecast for 1998/99, which suggests that small producers of this region still have concerns about using climate forecasts, despite the favorable impressions left by the 1997/98 Niño forecast. Reasons respondents cited for their reluctance relate to forecasts' spatial or temporal resolution. Forecasts cover seasonal conditions in a region rather than conditions in a farmer's specific location or those during shorter, critical time intervals (e.g., maize silking). Users' interests in the micro-climates of the region are a reflection of their concerns about forecasts' spatial resolution. Fewer than half our respondents $(43 \%)$ said that their sub-region's climate was similar to that of others close by. Another indication of farmers' concerns about sub-regional variation was that all farmers interviewed and in the focus groups maintained daily precipitation records, some extending back decades, as an attempt to understand 'one's own climate,' because it may be different from others'. ${ }^{4}$

Reluctance to use climate information is also partly an issue of trust, a common attitude in the context of technical innovations in agriculture. At the time of writing, the Argentine Meteorological Service issues 'experimental' rather than 'official' ENSO-based climate forecasts. Farmers expressed greater interest in the availability of 'good' forecasts than in recommen-

\footnotetext{
${ }^{3}$ Pielke (1998) has suggested that users who experienced the 1997/98 Niño might subsequently hold distorted views of forecasts. Pielke argues that the considerable magnitude of the 1997/98 Niño may 'anchor' users' expectations to that specific event, rather than the range of possibilities inherent in a categorical forecast. Writing about the 1997 Red River flood, Pielke (1998) and Burns (1999) also note that Grand Forks residents were unprepared since they had anchored to a specific, categorical forecast of flood height. Forecast providers and users must become more aware of cognitive illusions such as these, to realize greater economic value from climate forecasting

${ }^{4}$ The farmers we spoke with may well be exaggerating the degree of climatic heterogeneity they face, since the Pampas lack major orographic barriers or other factors that might cause substantial differences in microclimates. However their perceptions, inaccurate or not, will guide their adoption decisions
} 
dations about how to adjust farm management in response to ENSO forecasts. Use of ENSO-based climate forecasts is limited by the credibility of those forecasts to the farmers, an attitude evidently not swayed by research documenting the potential value of ENSO forecasting to agriculture in other settings.

\subsection{Users' knowledge of ENSO impacts on regional climate and crop production}

This portion of the survey sought from 100 respondents the source and degree of their knowledge about regional climate, as possible explanations for forecast use, or lack thereof. To build trust and promote acceptance of climate information, researchers must first understand users' prior beliefs and knowledge, since those will influence how users interpret events and new information (Stern \& Easterling 1999). Although producers surveyed were aware of ENSO, their knowledge of its effects on regional climate and crop production is incomplete (Table 2). Respondents were most knowledgeable about ENSO's climatic impacts. Most knew that the most important regional impact of Niños is either abundant (65\%) or excessive rain (32\%), and most (58\%) also knew that the most important regional impact of Niñas is insufficient rain. Knowledge of ENSO's effects on the region's crop yields was less consistent, however. Fewer than half the respondents $(48 \%)$ identified maize as the crop most likely to be affected by long-term predictions, as has been shown by other studies (e.g., Podestá et al. 1999a). Perhaps because of the strength of the 1997/98 event, most respondents (86\%) knew that Niños tend to improve maize yields, but fewer than half $(42 \%)$ were aware of Niñas' historically much stronger and detrimental effect on maize yields.

That users do not know some of ENSO's regional effects is unsurprising, because ENSO is a complex phenomenon characterized by substantial variability. While people may observe weather variability and extremes, climate is removed from direct experience because of its longer time scales. Users' knowledge gaps are problematic because the goal of realizing more economic value from ENSO-based climate forecasts requires users to understand them and to actively respond.

Overcoming users' knowledge gaps will likely not be easy, because local experience appears to be both a path- way and a constraint for the use of climate information. When asked how they learned about their region's climate, most respondents said either from their own experience $(61 \%)$ or from family elders $(18 \%)$, rather than from sources such as extension $(6 \%)$ or trade publications (5\%) that might disseminate ENSO-based climate forecasts. Length of a respondent's local experience appears to instill confidence in his or her perceived climate knowledge: a Kruskal-Wallis rank sum test $(p=0.0025)$ revealed a strong, positive correlation between the respondent's age and how well the respondent thought he or she knew the regional climate. Such confidence may lead users to judge that their farm or their decision making is less vulnerable to climatic variability and can discourage the use of climatic information (Burns 1999, Nicholls 1999).

Knowing more about how users assimilate climate information is essential to the task of promoting the use of that information. Potential users of ENSO-based climate forecasts will likely understand new information better and accept it more fully if they can interpret it in a causal model of climate variability that they understand and with which they agree (Stern \& Easterling 1999). We found evidence that increased exposure to ENSO-based climate forecasts and improved knowledge of regional ENSO effects each encourage respondents to use climatic information.

A respondent's source of regional climate knowledge and the accuracy of that knowledge each exerted a significant influence on his or her willingness to use climate information in our categorical regressions (i.e., probit). To test the hypothesis that knowledge source influences decisions of whether to use climate informa-

Table 3. Binomial probit regression of climate forecast use. Standard errors in parentheses. Statistical significance: ${ }^{*} 10 \%,{ }^{* *} 5 \%,{ }^{* * *} 1 \%$

\begin{tabular}{|c|c|c|c|}
\hline \multirow[t]{2}{*}{ Variable } & \multirow[t]{2}{*}{ Description } & \multicolumn{2}{|c|}{ Estimates } \\
\hline & & Coefficient & $t$ ratio \\
\hline Forecast use in 1998/99 & $\begin{array}{l}\text { Dependent variable } \\
(1=\text { yes; } 0=\text { no })\end{array}$ & & \\
\hline Age & $\mathrm{yr}$ & $\begin{array}{l}-0.017 \\
(0.010)\end{array}$ & $-1.67^{*}$ \\
\hline \multirow[t]{2}{*}{$\begin{array}{l}\text { Knowledge source } \\
\text { for regional climate }\end{array}$} & $\begin{array}{l}0=\text { family elders' or } \\
\text { own experience }\end{array}$ & $\begin{array}{c}0.840 \\
(0.322)\end{array}$ & $2.61^{* * *}$ \\
\hline & $\begin{array}{l}1 \text { = external sources, } \\
\text { such as extension or trade } \\
\text { publications }\end{array}$ & & \\
\hline No. of observations & 100 & & \\
\hline Constrained log likelihood & -68.03 & & \\
\hline Maximized log likelihood & -4.73 & & \\
\hline Likelihood ratio statistic $\left(\chi^{2}\right)$ & $126.61^{* * *}$ & & \\
\hline $\begin{array}{l}\text { McFadden's LRI } \\
\text { (likelihood ratio index) }\end{array}$ & 0.93 & & \\
\hline
\end{tabular}


tion, we estimated the respondent's most recent forecast use decision as a function of his or her age and climate knowledge source.

The probit specification estimates the conditional probability of a respondent's forecast use, given that respondent's age and how he or she learned about climate (Table 3). Age exerted a negative influence (Student's $t=$ -1.67), while those who did change decisions in response to the 1998/99 Niña forecast were more likely to have learned regional climate from sources other than family elders or their own experience (Student's $t=2.27$ ). The likelihood ratio statistic $\left(\chi^{2}\right)$ allows us to reject the hypothesis that these coefficients jointly equal zero $(\mathrm{p}<$ 0.0001).

To test the hypothesis that accuracy of knowledge influences willingness to use climate information, we estimated the respondent's evaluation of the importance of climate information in 1997/98, compared with previous years, as a function of the respondent's age, farm size, whether maize is his or her principal crop and whether he or she knew that maize is the regional crop most likely to benefit from climate information (Table 4).

The effect of age was insignificant, but the other explanatory variables exerted significant, positive effects. Most importantly, farmers aware that maize is the most ENSO-relevant crop were more likely to see climate information as more useful in 1997/98 than in previous years (Student's $t=3.01$ ). Again the likelihood ratio statistic allows us to reject the hypothesis that all coefficients jointly equal zero $(p<0.0001)$

Both findings suggest that users' cognitive framework and belief set condition their acceptance of and responses to ENSO-based climate forecasts. Parallel research on climate change has also found a correlation between the accuracy of users' understanding of climate and their acceptance of mitigation responses (Kempton et al. 1995, Bord et al. 1998). Promotion of ENSO-based climate forecasts should begin by educating users about ENSO and how it affects local climate. Those who deliver the message should learn how their audience thinks about climate. ${ }^{5}$

\subsection{Example of a user's adoption decision}

An example may help illustrate the importance of our findings. Transcripts from our focus groups indi- cate that the diffusion of information related to the 1997/98 Niño depended upon the farmers' trust of the different forecast sources (e.g., trade organizations, extension, telecommunications media and word of mouth; Llovet 1998). Thus, we find statements about 2 divergent situations. Most farmers became acquainted with ENSO sometime in mid-1997 through Clarín Rural, the Saturday agricultural supplement in the most widely read national newspaper. Few farmers mentioned the specific content of the forecast, suggesting that, at least initially, few gave it much thought.

One farmer did say he had received useful climate information from a seed company with greater lead time and detail, along with related management advice. The first time this farmer heard of ENSO was in a conversation with his seed dealer, in mid-1997, following the 'brutal drought' of 1996:

\begin{abstract}
'According to the satellite information, there would be no problems this year, because the Niño was going to come. We just had this terrible drought, so it did not seem possible. When we first heard the Niño forecast, we began to see that we should change crop management. At first no one believed it. They (satellite images) showed, for example, that for this region and this week that we needed application, because by the weekend or soon afterwards there would be rain. Then, I believed the person who said that must be some kind of guru, because of the suggested precision. But what he divined came very close to happening. When you can obtain information
\end{abstract}

${ }^{5}$ For more on how humans assimilate climatic information, see Nicholls (1999) and Stern \& Easterling (1999, p. 71-94) 
that is not lies or a guru's revelation but instead is precise fact, that information becomes essential for production. I could not believe the precision, because I had always managed my farm the way my grandfather and our ancestors had. This is quite different from US satellites telling us that this region has a higher probability of rain, carefully noted on a map. It did not seem possible, that the obtained information was going to be precise enough. While there are days to the contrary, the forecast has been good.' 6

The stages of this producer's adoption decision are commonly observed in agro-technology transfer: initial incredulity, experimentation, and outcome evaluation. At first, the farmer gave the forecast source little credibility, comparing him to a religious guru, and continued to rely on his local experience. Experimentation with recommended practices (more fertilizer applications) met with a favorable outcome because the forecasted rains enabled greater nutrient uptake and crop growth. The 1997/98 Niño may represent a turning point in Pampean farmers' perception and attitude toward ENSO-based climate forecasts. Several focus group participants voiced similar views about the demonstrated value of ENSO-based climate forecasts.

More to the point, throughout his statement the farmer spoke of short-term weather forecasts (i.e., daily to weekly) and seasonal climate forecasts as if they were the same. Specifically, the farmer first mentioned climatic events (drought and Niño), then seamlessly digressed into a weather discussion (weekend rain) and finally judged the ENSO-based climate forecast on the basis of weather events. While our focus group monitor carefully stressed the difference in time scales between weather and climate, the farmer's terminology ('satellite information') did not and suggests a critical knowledge gap. In particular, the farmer used daily or weekly weather to evaluate the ENSO-based climate forecast. That the 1997/98 Niño forecast received favorable user evaluations like this one is a mixed blessing, creating unrealistic user expectations, ${ }^{7}$ because ENSO-based climate forecasts do not predict daily or weekly weather. Subsequent ENSO-based climate forecasts may not pass muster even if 'correct' by the standards of the research community.

\footnotetext{
${ }^{6}$ Text of this conversation in its original Spanish is available upon request from the first author

${ }^{7}$ Nicholls (1999) argues that forecasts of the 1997/98 Niño were not uniformly successful and that views to the contrary exhibit 'hindsight bias', wherein knowledge of an outcome such as the 1997/98 Niño increases an individual's belief about the degree to which he or she would have predicted that outcome, without the benefit of that knowledge. If true, hindsight bias would encourage users to view future forecasts as being unrealistically accurate
}

Farmers are familiar with weather forecasts, so the temptation may be simply to graft the new information, ENSO-based climate forecasts, onto what they already know, i.e., their 'mental models' (Morgan et al. 1992). That assimilation of new information to fit existing concepts is what anthropologists call 'syncretism' (Kempton et al. 1995, p. 68). The danger is that fundamentally flawed mental models can pose a significant obstacle to learning. For example, Kempton et al. (1995) identified confusion in public perceptions of stratospheric ozone depletion and global climate change: most interviewees failed to mention any link between the greenhouse effect and fossil fuel combustion, instead suggesting that giving up hairspray would slow global warming. If users are to evaluate ENSO-based climate forecasts properly, outreach efforts must address preexisting mental models and stress the differences between weather- and climate forecasting.

The predictability and magnitude of the 1997/98 Niño may be an opportunity to stimulate learning and preparedness for future events, which may not be as easily predicted. To promote climatic information, we should make clear which forecasts and decisions are appropriate to which time scales. We should also provide users with the opportunity to follow forecasting progress, to balance the disagreements in competing forecasts, and to express their needs (Pulwarty 1997).

\section{CONCLUSIONS}

The economic value of climate information is determined not by climatic impacts alone but also by individuals who decide if and how to use that information. To promote the use of ENSO-based climate forecasts in regional agriculture, or to estimate their economic value, research must first assess users' interpretations of forecasts. Our case study offers a specific context for climate information in agricultural decision making and conclusions of broader relevance. Pergamino or any other location cannot serve as a basis for generalizing to all others, nor should the farmer population we surveyed be considered representative of other agricultural forecast users, such as distributors and input suppliers. For a more complete statement of our placebased methodology to assess local climate information needs, see Podestá et al. (in press). By 'particularizing' (Stake 1995) the use of climate information to a specific context, our case study suggests that researchers and policy officials who neglect user needs and perceptions do so at the expense of their ability to provide meaningful appraisal and prescription.

Obstacles to forecast use remain but become more evident upon consideration of local resource and cultural conditions. One such obstacle is the hetero- 
geneous set of ENSO signals that producers cite and that we have found in Pampean crop production variables. Users identified forecast scale and the reliability of the source of forecast information as critical obstacles to adoption. For a given event, some sub-regions of the Pampas are drier, others wetter, but this pattern is not constant for all events. In addition, we have found substantial inter-event variability, as is typical of extra-tropical climates (Podestá et al. 1999b). The variability of precipitation anomalies for a given ENSO phase (e.g., all Niño years) is comparable to the total variability (i.e., all years), except during a few welldefined periods. This means that, although, on average, Niño summers tend to be wetter, a given Niño event may be dry, normal, or wet. An implication is that research and outreach to downscale forecasts temporally and spatially would help close the gap of expectations between forecast user and provider, and would facilitate trust building between the two that must precede adoption.

To overcome obstacles such as forecast scale and reliability, researchers promoting climatic information must appreciate users' prior beliefs and knowledge, rather than presume a clean slate. What users already know and believe influences their interpretation of climatic events and information (Stern \& Easterling 1999). While our respondents were aware of ENSO, their knowledge of its effects on regional climate and crop production was incomplete. Local experience is how most respondents learned about regional climate, but longer local experience appeared to diminish concerns about climatic variability and to deter use of climatic information. Two positive findings are that increased exposure to ENSO-based climate forecasts and improved knowledge of regional ENSO effects each appeared to encourage respondents to use climatic information.

The 1997/98 Niño also encouraged the respondents and was a key event in the development of awareness and concern about ENSO in Pergamino, as it was worldwide. Whether that visibility will mean greater sustained use of climatic information in Pampean agriculture is hard to say, however. Some respondents appeared to confuse the different time scales of weather- and climate forecasting. That the forecast of the 1997/98 Niño received favorable user evaluations may be a mixed blessing, creating unrealistic user expectations, because ENSO-based climate forecasts cannot predict daily or weekly weather. As Slovic (1987) and Burns (1999) have noted, misleading personal experience can lead to risks being misjudged.

Our findings suggest that the fundamental structure of forecast use decisions cannot be divorced from their local content and imply that the estimated economic value of climate forecasts loses meaning if separated from their context of use. Such a finding is consistent with traditional economic and other social science research on technology diffusion in agriculture (Agrawala \& Broad in press). In promoting agricultural use of ENSO-based climate forecasts, researchers should recall Theodore Schultz's seminal (and Nobel prize winning) work on technology diffusion, Transforming Traditional Agriculture (Schultz 1964). Agricultural technology, argued Schultz, is highly 'location specific' and must be adapted to the cultural and resource conditions where it is to be applied. As Wendell Berry (1977) wrote, the problem is not one of choosing between scientific and local knowledge, but of creating conditions in which these separate realities can inform one another. Whether ENSO-based climate forecasts have been or can be sufficiently adapted for local uses are important topics for further research.

Acknowledgements. This research has been supported by grants from the National Oceanic and Atmospheric Administration (Office of Global Programs) and the National Science Foundation (Methods and Models for Integrated Assessment Initiative) to a Consortium of Florida Universities (University of Miami, University of Florida and Florida State University). The Inter-American Institute for Global Change Research (IAI) provided additional funding as part of its Initial Science Program. We are also grateful to G. Varela of INTA's Cambio Rural program in Pergamino for his work in implementing the survey. We thank Roger Pulwarty, the anonymous CR reviewers, Kenny Broad, James Hansen, B. D. McCullough, Carlos Messina and Ethel Terreno for helpful comments.

\section{LITERATURE CITED}

Adams RM, Chen CC, McCarl BA, Weiher RF (1999) The economic consequences of ENSO events for agriculture. Clim Res 13:165-172

Agrawala S, Broad K (in press) Technology transfer perspectives on climate forecast applications. Knowl Soc

Barnston A, Glantz MH, He Y (1999) Predictive skill of statistical and dynamical climate models in SST forecasts during the 1997-98 El Niño episode and the 1998 La Niña onset. Bull Am Meteorol Soc 80:217-243

Basualdo EM (1995) El nuevo poder terrateniente: una respuesta. Real Econ 132:126-149

Berry W (1977) Unsettling of America: culture and agriculture. Avon Books, New York

Bord RJ, Fisher A, O'Connor RE (1998) Public perceptions of global warming: United States and international perspectives. Clim Res 11:75-84

Broad K, Pfaff ASP, Glantz MH (in press) Effective and equitable dissemination of seasonal-to-interannual climate forecasts. Clim Change

Burns DH (1999) Perceptions of flood risk: a case study of the Red River flood of 1997. Water Resour Res 35:3451-3458

Changnon SA (1996) Comments on the marketing of science: users are a key. Bull Am Meteorol Soc 77:2729-2735

Changnon SA (1999) Rapidly expanding uses of climate data and information in agriculture and water resources: causes and characteristics of new applications. Bull Am Meteorol Soc 80:821-830 
Changnon SA, Changnon JM, Changnon D (1995) Uses and applications of climate forecasts for power utilities. Bull Am Meteorol Soc 76:711-720

Cohen SJ (1997) Scientist-stakeholder collaboration in integrated assessment of climate change: lessons from a case study of Northwest Canada. Environ Model Assess 2: 281-293

Easterling W (1986) Subscribers to the NOAA Monthly and Seasonal Weather Outlook. Bull Am Meteorol Soc 67: 402-410

Easterling W, Mendelsohn R (in press) Estimating the economic impacts of drought on agriculture. In: Wilihite DA (ed) Natural hazards and disasters. Routledge, London

Feldman MS (1989) Order without design: information production and policymaking. Stanford University Press, Palo Alto, CA

Ferreyra RA, Podestá GP, Messina CD, Letson D, Dardanelli J, Guevara E, Meira S (2001) A linked-modeling framework to estimate maize production risk associated with ENSO-related climate variability in Argentina. Agric For Meteorol 107:177-192

Fischhoff B (1994) What forecasts (seem to) mean. Int J Forecast 10:387-403

Freudenburg W, Rursch J (1994) The risks of putting the numbers in context. Risk Anal 14:949-958

Funtowicz S, Ravetz J (1990) Uncertainty and quality in science for policy. Kluwer, Boston

Glantz MH (1977) The value of a long-range weather forecast for the West African Sahel. Bull Am Meteorol Soc 58: $150-158$

Glantz MH (1982) Consequences and responsibilities in drought forecasting: the case of Yakima, 1977. Water Resour Res 18:3-13

Glantz MH (1996) Currents of change: El Niño's impact on climate and society. Cambridge University Press, Cambridge

Grondona MO, Podestá GP, Bidegain M, Marino M, Hordij H (2000) A stochastic precipitation generator conditioned on ENSO phase: a case study in southeastern South America. J Clim 13:2973-2986

Hall AJ, Rebella CM, Ghersa CM, Culot JP (1992) Field crop systems of the Pampas. In: Pearson CJ (ed) Ecosystems of the world. Field crop ecosystems. Elsevier, Amsterdam, p 413-449

INTA/SAGPyA (1998) Impacto económico de las inundaciones en las provincias del norteste Argentina. Working paper from INTA/Instituto de Economia y Sociologia, Buenos Aires

Inter-American Development Bank (1999) Basic socio-economic data report: Argentina. Statistics and Quantitative Analysis Unit, Integration and Regional Programs Department, November 15, IADB, Washington, DC

Jochec KG, Mjelde JW, Lee AC, Conner JR (in press) Use of seasonal climate forecasts in rangeland-based livestock operations in west Texas. J Appl Meteorol

Johnson SR, Holt MT (1997) The value of weather information. In: Katz RW, Murphy AH (eds) The economic value of weather and climate forecasts. Cambridge University Press, Cambridge, p 75-107

Kempton W, Boster JS, Hartley JA (1995) Environmental values in American culture. MIT Press, Cambridge, MA

Lamb PJ (1981) Do we know what we should be trying to forecast_climatically? Bull Am Meteorol Soc 62:1000-1001

Llovet I (1998) Actitudes y percepciones de productores agropecuarios frente a la información climática. Presented paper, Universidad Nacional de Quilmes

McPhaden MJ (1999) Genesis and evolution of the 1997-98 El Niño. Science 283:950-954
Messina CD, Hansen JW, Hall AJ (1999) Land allocation conditioned on ENSO phases in the pampas of Argentina. Agric Syst 60:197-212

Mjelde JW, Sonka ST, Dixon BL, Lamb PJ (1988) Valuing forecast characteristics in a dynamic agricultural production system. Am J Agric Econ 70:674-684

Mjelde JW, Peel DS, Sonka ST, Lamb PJ (1993) Characteristics of climate forecast quality: implications for economic value to Midwestern corn producers. J Clim 11:2175-2187

Mjelde JW, Thompson TN, Nixon CJ (1996) Government institutional effects on the value of seasonal climate forecasts. Am J Agric Econ 78:175-188

Mjelde JW, Thompson TN, Nixon CJ, Lamb PJ (1997) Utilizing a farm-level decision model to help prioritize future climate prediction research needs. Meteorol Appl 4: 161-170

Mjelde JW, Hill HSJ, Griffiths JF (1998) A review of current evidence on climate forecasts and their economic effects in agriculture. Am J Agric Econ 80:1089-1095

Morgan MG, Fischhoff B, Bostrom A, Lave L, Atman CJ (1992) Communicating risk to the public: first, learn what people know and believe. Environ Sci Technol 26: 2048-2056

Murphy A, Brown BG (1983) Forecast terminology: composition and interpretation of public weather forecasts. Bull Am Meteorol Soc 64:13-22

Nicholls N (1999) Cognitive illusions, heuristics and climate prediction. Bull Am Meteorol Soc 80:1385-1397

Offutt S (1993) Bridging the gap between policymakers and academics. In: Kaiser HM, Drennen TE (eds) Agricultural dimensions of global change. St. Lucie Press, St. Lucie, FL

Parellada GH, Brescia V, Lema D (1998) Los costos del clima: impacto económico sobre los cultivos pampeanos. Nuestro Campo 6:15-17

Paruelo JM, Sala OE (1993) Effect of global change on maize production in the Argentinean Pampas. Clim Res 3: 161-167

Pielke RA Jr (1998) What is a good forecast? WeatherZine, February, Lead editorial, NCAR monthly electronic newsletter, Issue \#8; available at www.esig.ucar.edu/socasp/ zine/

Pielke RA Jr, Glantz MH (1995) Serving science and society: lessons from large-scale atmospheric science programs. Bull Am Meteorol Soc 76:2445-2457

Pielke RA Jr, Sarewitz D, Byerly R Jr (2000) Decision making and the future of nature. In: Pielke RA Jr, Sarewitz D, Byerly R Jr (eds) Prediction: science, decision making and the future of nature. Island Press, Covelo, CA, p 361-387

Podestá GP, Magrin GO, Travasso M (1997) Report of a meeting with representatives of organizations of decision-makers from the agricultural sector of Argentina. Available from University of Miami/Rosenstiel School of Marine and Atmospheric Science

Podestá GP, Messina CD, Grondona MO, Magrin GO (1999a) Associations between grain crop yields in central-eastern Argentina and El Niño-Southern Oscillation. J Appl Meteorol 38:1488-1498

Podestá GP, Letson D, O'Brien J, Jones J, Legler D, Hansen J (1999b) Regional application of ENSO-based climate forecasts to agriculture in the Americas. In: US Dept Commerce/NOAA/OGP Economics \& Human Dimensions Principal Investigators Meeting, April 26-28, Tucson, AZ; available at http://www.ogp.noaa.gov/mpe/econhd/fy99/ prjtsums8_99.htm

Podestá G, Letson D, Messina CD, Royce F, Ferreyra RA, Jones JW, Hansen JW, Llovet I, Grondona M, O'Brien JJ et al. (in press) Use of ENSO-related climate information in 
agricultural decision making in Argentina: a pilot experience. Agric Syst

Pulwarty RS (1997) Societal and perceptual constraints on the use of forecasts. In: A systems approach to ENSO. UCAR/ESIG workshop presentation; available at www. esig.ucar.edu/enso

Pulwarty RS, Redmond KT (1997) Climate and salmon restoration in the Columbia River basin: the role and usability of seasonal forecasts. Bull Am Meteorol Soc 78: 381-397

Robinson JB (1992) Risks, predictions and other optical illusions: rethinking the use of science in social decision making. Policy Sci 25:237-254

Royce F, Meira S, Jones J (1997) Current perceptions and potential uses of climate predictions by farmers of the humid pampas. Fl Consort Tech Rep FC-UF-2000-03, Univ of Florida/IFAS, Gainsville

Schultz TW (1964) Transforming traditional agriculture. Yale University Press, New Haven

Selley RA, Wilson PN (1997) Risk research and public outreach: a tale of two cultures? J Agric Resour Econ 22:222-232

Slovic P (1987) Perceptions of risk. Science 236:280-285

Solow A, Adams R, Bryant K, Legler D, O'Brien J, McCarl B, Nayda W, Weiher R (1998) Value of improved ENSO pre-

Editorial responsibility: Roger Pulwarty, Silver Spring, Maryland, USA diction to US agriculture. Clim Change 39:47-60

Sonka ST, Changnon SA, Hofing S (1988) Assessing climate information use in agribusiness II: decision experiments to estimate economic value. J Clim 1:766-774

Stake RE (1995) The art of case study research. Sage Publishers, Thousand Oaks, CA

Stern PC, Easterling WE (eds) (1999) Making climate forecasts matter. National Research Council, Panel on Human Dimensions of Seasonal-to-Interannual Climate Variability, National Academy Press, Washington, DC

Stewart T (1997) Forecast value: descriptive decision studies. In: Katz R, Murphy A (eds) Economic value of weather and climate forecasts. Cambridge University Press, Cambridge, p 147-181

Weiher R (ed) (1999) Improving El Niño forecasting: the potential economic benefits. US Dept Commerce/National Oceanic and Atmospheric Administration/Office of Policy and Strategic Planning, Washington, DC

Wilks DS (1997) Forecast value: prescriptive decision studies. In: Katz R, Murphy A (eds) Economic value of weather and climate forecasts. Cambridge University Press, Cambridge, p 109-145

Yin RK (1994) Case study research design and methods. Sage Publishers, Thousand Oaks, CA

Submitted: March 15, 2001; Accepted: June 22, 2001

Proofs received from author(s): September 13, 2001 